\title{
PENGARUH CURRENT RATIO, TOTAL ASSETS TURNOVER, DEBT TO EQUITY RATIO, DAN RETURN ON EQUITY TERHADAP HARGA SAHAM PADA PERUSAHAAN YANG TERDAFTAR DI JII PERIODE 2009-2013'1
}

Puput Novitasari

Mahasiswa Program Studi S1 Ekonomi Islam-Fakultas Ekonomi dan Bisnis-Universitas Airlangga Email : puputnovitasari27@gmail.com

Leo Herlambang

Departemen Ekonomi Syariah-Fakultas Ekonomi dan Bisnis-Universitas Airlangga Email : leo.herlambang@gmail.com

\begin{abstract}
:
Islamic stocks in implementation are not contrary to the principles of sharia. Before investing their money investors should pay attention to advance the company's performance. One of its attention is fundamental analysis based on financial ratios. This research aims to analyze the effect of Current Ratio, Total Assets Turnover, Debt to Equity Ratio, and Return on Equity of stock price companies that listed on Jakarta Islamic Index in 2009-2013. The subject is the consistent companies listed on Jakarta Islamic Index during the research period. Selection method of the population is purposive sampling. Analysis method is multiple linear regression with significance level 0.05. The results indicate theese variables as a partially and simultaneuously insignificant influence on the stock prices. The value of coefficient determination 0.144 shows that $14.4 \%$ the stock prices is influenced by theese variables, while for $85,6 \%$ are affected by other variables that are not included in this research.
\end{abstract}

Keywords: Stock Price, Jakarta Islamic Index, Current Ratio, Total Assets Turnover, Debt to Equity Ratio, Return On Equity.

\section{PENDAHULUAN}

Pemahaman investasi secara mendalam pada era modern ini menjadi hal yang sangat penting bagi pihak yang ingin menempatkan dananya pada tempat yang profitable. Untuk mencapai utiliti atau meningkatkan keuntungan demi mendapatkan kemakmuran di masa mendatang tentunya dibutuhkan keputusan penempatan investasi yang efektif dan efisien. Islam menganjurkan kita melakukan investasi dengan menyimpan, mengelola, dan mengembangkan harta untuk menjamin kehidupan di masa mendatang. Investasi yang dibolehkan dalam Islam haruslah bersifat halal, sehingga pada penelitian ini menggunakan perusahaan-perusahaan yang terdaftar dalam Jakarta Islamic 1) Jurnal ini merupakan bagian dari skripsi yang ditulis oleh (Puput Novitasari : 041114094), yang diuji pada 16 Februari 2015.

Index yang merupakan indeks yang berisi dengan 30 saham yang memenuhi kriteria investasi berdasarkan syariah Islam.

Investor harus memperhatikan dahulu kinerja perusahaan sebelum menginvestasikan dananya. Salah satunya dengan melakukan analisis fundamental yang berbasis rasio keuangan. Sudana (2009:22) menyatakan bahwa analisis laporan kevangan penting dilakukan untuk mengetahui kekuatan dan kelemahan suatu perusahaan.

Perusahaan yang terdaftar di JII adalah 30 perusahaan dengan volume perdagangan tertinggi. Sedangkan perusahaan yang terdaftar di Jll selalu berubah-ubah setiap enam bulan sekali, yang menunjukkan perubahan minat investor dalam memilih saham untuk dijual 
maupun dibeli, dan tentunya ada faktorfaktor yang mempengaruhi. Pada penelitian ini akan diteliti faktor-faktor fundamental perusahaan yaitu kinerja keuangan perusahaan.

Tabel 1.

Perubahan Perusahaan Syariah yang Terdaftar di JII Periode 2009-2013

\begin{tabular}{|l|l|c|}
\hline No. & Periode & $\begin{array}{l}\text { Perubahan } \\
\text { Perusahaan } \\
\text { dan Masuk) }\end{array}$ \\
\hline 1 & 2009 Semester 2 & 3 \\
\hline 2 & 2010 Semester 1 & 7 \\
\hline 3 & 2010 Semester 2 & 4 \\
\hline 4 & 2011 Semester 1 & 9 \\
\hline 5 & 2011 Semester 2 & 3 \\
\hline 6 & 2012 Semester 1 & 3 \\
\hline 7 & 2012 Semester 2 & 4 \\
\hline 8 & 2013 Semester 1 & 2 \\
\hline
\end{tabular}

Sumber: www.idx.co.id

Investor harus memperhatikan harga saham yang akan dibeli. Karena investor mengharapkan keuntungan dari investasi yang dilakukannya, termasuk keuntungan yang diperoleh dari adanya kenaikan atau penurunan harga saham. Sementara fenomena harga saham di pasar modal selalu mengalami pergerakan yang fluktuatif, yang dibuktikan dengan grafik pergerakan harga Jakarta Islamic Index berikut ini.

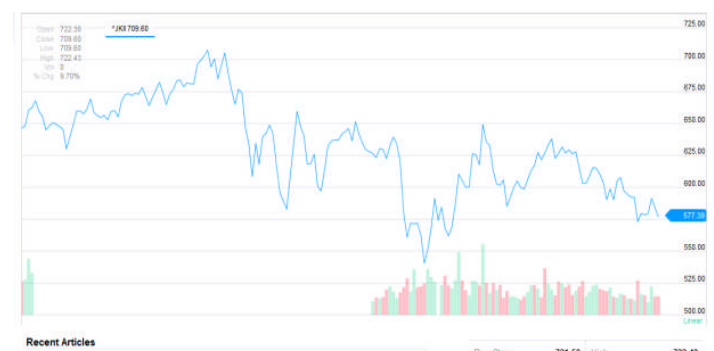

Sumber: finance.yahoo.com

Gambar 1.

Pergerakan Harga Jakarta Islamic Index Dari grafik di atas menunjukkan harga saham yang tergabung dalam Jakarta Islamic Index sepanjang tahun 2013 mengalami perubahan kenaikan maupun penurunan setiap waktu. Oleh sebab itu perlu dilakukan penelitian mengenai faktor-faktor yang mempengaruhi perubahan harga saham, termasuk kondisi fundamental perusahaan.

Berdasarkan uraian yang telah dijelaskan, maka peneliti dapat merumuskan masalah penelitian sebagai berikut:

1. Apakah Current Ratio, Total Asset Turnover, Debt to Equity Ratio, dan Return on Equity secara parsial berpengaruh signifikan terhadap harga saham perusahaan yang terdaftar di JII periode 2009-2013?

2. Apakah Current Ratio, Total Asset Turnover, Debt to Equity Ratio, dan Return on Equity secara simultan berpengaruh signifikan terhadap harga saham perusahaan yang terdaftar di JII periode 2009-2013?

Adapun tujun penelitian ini adalah untuk menganalisis secara parsial meupun simultan pengaruh Current Ratio, Total Asset Turnover, Debt to Equity Ratio, dan Return on Equity terhadap harga saham perusahaan yang terdaftar di JII periode 2009-2013.

\section{LANDASAN TEORI}

Undang-Undang Pasar Modal No. 8 tahun 1995 tentang pasar modal mendefinisikan pasar modal sebagai berikut.

kegiatan yang bersangkutan dengan penawaran umum dan perdagangan efek, perusahaan publik yang berkaitan dengan efek yang diterbitkannya, serta lembaga dan profesi yang berkaitan dengan efek. 
Dalam mengembangkan investasi syariah di pasar modal Indonesia OJK beserta BEl selalu melakukan kerjasama dengan Dewan Syariah Nasional Majelis Ulama Indonesia (DSN MUI). Fatwa investasi syariah di pasar modal ada pada fatwa No.80/DSN-MUI/III/2011 tentang penerapan prinsip syariah dalam mekanisme perdagangan efek bersifat ekuitas di pasar reguler bursa efek.

\section{Signaling Theory}

$$
\text { Weston dkk }
$$

mengemukakan sinyal sebagai berikut.

signal is an action taken by a firm's management that provides clues to investors about how management views the firm's prospects.

Informasi yang dipublikasikan

sebagai suatu pengumuman akan memberikan sinyal bagi investor dalam pengambilan keputusan investasi. Jogiyanto (2013:586) menyatakan jika pengumuman mengandung nilai positif, maka diharapkan pasar akan bereaksi pada waktu pengumuman tersebut diterima oleh pasar. Informasi yang lengkap, relevan, akurat dan tepat waktu sangat diperlukan oleh investor di pasar modal sebagai alat analisis untuk mengambil keputusan investasi.

Asumsi dari signaling theory adalah para manajer perusahaan memiliki informasi yang lebih akurat mengenai perusahaan yang tidak diketahui oleh pihak luar (investor). Hal ini akan mengakibatkan suatu asimetri informasi antara pihak-pihak yang berkepentingan. Jogiyanto (2013:564) menjelaskan asimetrik informasi sebagai suatu kondisi yang menunjukkan sebagian investor memiliki informasi dan yang lainnya tidak memilikinya.

Islam telah mengajarkan untuk selektif dalam menerima informasi yang ada, agar tidak menjadikan kita celaka. Sebagaimana firman Allah dalam QS. AI Hujurat: 6.

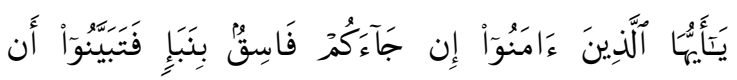

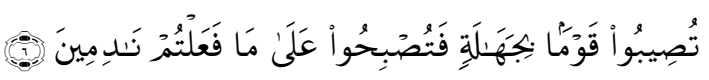

Artinya: "Hai orang-orang yang beriman, jika datang kepadamu orang fasik membawa suatu berita, maka periksalah dengan teliti agar kamu tidak menimpakan suatu musibah kepada suatu kaum tanpa mengetahui keadaannya yang menyebabkan kamu menyesal atas perbuatanmu itu".

\section{Analisis Fundamental}

Analisis fundamental digunakan untuk mengidentifikasi prospek perusahaan melalui analisis faktor-faktor yang mempengaruhinya agar dapat diperkirakan harga saham di masa yang akan datang (Husnan, 2009:48). Dalam mengambil keputusan investor mempertimbangkan nilai yang mencerminkan nilai saham sebenarnya, salah satunya adalah nilai intrinsik atau nilai fundamental. Jogiyanto (2013:160) mendefinisikan nilai fundamental sebagai nilai seharusnya dari suatu saham.

\section{Laporan Keuangan}

Fahmi (2013:28) mendefinisikan laporan kevangan sebagai gambaran yang menjelaskan tentang kondisi keuangan suatu perusahaan. Menurut Pernyataan Standar Akuntansi Keuangan 
Syariah (2009:11) tujuan laporan kevangan adalah menyediakan informasi yang menyangkut posisi keuangan, kinerja, serta perubahan posisi keuangan suatu entitas syariah yang bermanfaat bagi sejumlah besar pemakai dalam pengambilan keputusan ekonomi.

\section{Pengukuran Kinerja Keuangan}

Noor (2009:220) menjelaskan bahwa pengukuran kinerja perusahaan merupakan kegiatan yang ditujukan untuk menilai keberhasilan pengelolaan suatu perusahaan. Untuk mengevaluasi kinerja dan kondisi keuangan perusahaan, analis keuangan dan pemakai laporan keuangan harus melakukan analisis terhadap kesehatan perusahaan menggunakan alat yang biasa digunakan yaitu rasio keuangan (Darsono dan Ashari, 2005:51). Analisis rasio menurut Sundjaja dan Barlian (2003:128) adalah suatu metode perhitungan dan interpretasi rasio keuangan untuk menilai kinerja dan status suatu perusahaan.

\section{Rasio Likuiditas}

Syamsuddin (2009:41) menjelaskan likuiditas sebagai suatu indikator mengenai kemampuan perusahaan untuk membayar semua kewajiban finansial jangka pendek pada saat jatuh tempo dengan menggunakan aktiva lancar yang tersedia. Rasio lancar (Current Ratio) adalah ukuran yang sering digunakan atas solvensi jangka pendek (Syamsuddin, 2009:43). Syamsuddin (2009:44) "...tingkat current ratio 2,00 sudah dianggap baik (concidered acceptable)".

\section{Rasio Aktivitas}

Besar atau kecilnya activity ratio dapat diukur dengan beberapa cara yaitu inventory turnover, average days in inventory, receivable turnover, days sales out standing, fixed assets turnover, total assets turnover (Sudana, 2009:24). Total assets turnover mengukur efektivitas penggunaan seluruh aktiva dalam menghasilkan penjualan, sehingga semakin besar nilai dari rasio ini menunjukkan semakin efektif pengelolaan seluruh aktiva yang dimiliki perusahaan, (Sudana, 2009:25).

\section{Rasio Solvabilitas}

Rasio solvabilitas atau rasio hutang mengukur berapa besar penggunaan hutang dalam pembelanjaan perusahaan, (Sudana, 2009:23). Tampubolon (2005:37) menyatakan apabila perusahaan gagal dalam memenuhi pelunasan hutang, maka dapat menyebabkan kesulitan keuangan dan pada akhirnya yang terjadi adalah kebangkrutan.

\section{Rasio Profitabilitas}

Menurut Sudana (2009:25), profitability ratio mengukur kemampuan perusahaan untuk menghasilkan laba dengan sumber-sumber yang dimiliki perusahaan seperti aktiva, modal, atau penjualan perusahaan. Menurut Weston dan Brigham (1993:305) rasio Return on Equity mengukur tingkat pengembalian atas investasi bagi pemegang saham biasa.

\section{Hipotesis dan Model Analisis}

Berdasarkan latar belakang, perumusan masalah, serta landasan teori 
maka hipotesis yang diajukan dalam penelitian ini adalah sebagai berikut:

$\mathrm{HI}=$ Current Ratio, Total Asset Turnover, Debt to Equity Ratio, dan Return on Equity secara parsial berpengaruh signifikan terhadap harga saham.

H2 = Current Ratio, Total Asset Turnover, Debt to Equity Ratio, dan Return on Equity secara simultan berpengaruh signifikan terhadap harga saham.

\section{Model Analisis}

Model analisis penelitian ini disusun berdasarkan variabel-variabel penelitian.

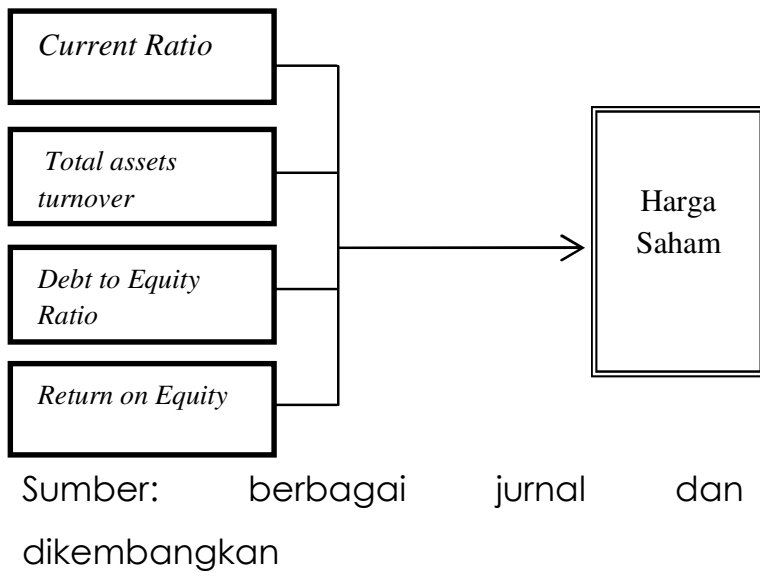

Gambar 2.

Model Analisis

$Y=\beta_{0}+\beta_{1} X_{1}+\beta_{2} X_{2}+\beta_{3} X_{3}+\beta_{4} X_{4}+e$

$\beta_{0}=$ koefisien persamaan regresi

$\beta_{1}, \beta_{2}, \beta_{3}, \beta_{4}=$ koefisien regresi variabel $X_{1}, X_{2}$,

$\mathrm{X}_{3}, \mathrm{X}_{4}$

$\mathrm{X}_{1}=$ variabel Current Ratio

X2 $=$ variabel Total Assets Turnover (TATO)

X3 = variabel Debt to Equity Ratio

X4= variabel Return On Equity

$\mathrm{e}=$ disturbance error .

\section{METODE PENELITIAN}

Penelitian ini menggunakan pendekatan kuantitatif untuk mengetahui pengaruh antar variabel menggunakan rumus matematis, teori, serta hipotesis pada variabel yang berkaitan.

\section{Identifikasi Variabel}

Variabel dependen penelitian ini adalah harga saham perusahaan yang terdaftar dalam Jll pada periode 20092013. Varibel independen penelitian ini adalah rasio keuangan Current Ratio, Total Asset Turnover, Debt to Equity Ratio, dan Return on Equity .

\section{Definisi Operasional Variabel}

Harga Saham

Harga saham merupakan nilai saham sebagai akibat dari suatu transaksi diperjualbelikannya saham tersebut di pasar. Dalam penelitian ini harga saham yang digunakan adalah harga saham tahunan yang diambil dari closing price setiap akhir tahun selama periode 20092013 yang dipublikasikan dalam situs resmi yahoo finance. Ukuran variabel harga saham adalah dalam bentuk Rupiah.

\section{Current Ratio}

Merupakan rasio lancar yang mengukur kemampuan perusahaan dalam memenuhi hutang jangka pendek dengan menggunakan aktiva lancar yang dimiliki. Curent ratio didapatkan dari laporan kevangan dalam annual report perusahaan selama periode 2009-2013 yang dipublikasikan di situs resmi BEI. Ukuran current ratio adalah dalam bentuk rasio.

Rumus: Current Ratio $=\frac{\text { Current Assets }}{\text { Current Liabilities }}$

Total Asset Turnover

Merupakan rasio untuk mengukur kemampuan manajemen perusahaan 
dalam melakukan efisiensi operasionalnya. Total asset turnover didapatkan dari laporan kevangan dalam annual report perusahaan selama periode 2009-2013 yang dipublikasikan di situs resmi BEI. Ukuran total asset turnover adalah dalam bentuk rasio.

Rumus: Total Assets Turnover $=\frac{\text { Sales }}{\text { Total Assets }}$

Debt to Equity Ratio

$$
\text { Merupakan rasio untuk }
$$
menggambarkan prosentase hutang jangka panjang terhadap ekuitas. Debt to equity ratio didapatkan dari laporan keuangan dalam annual report perusahaan selama periode 2009-2013 yang dipublikasikan di situs resmi BEI. Ukuran debt to equity ratio adalah dalam bentuk rasio.

Rumus: Debt to Equity Ratio $=\frac{\text { Long-term Debt }}{\text { Total Equity }}$

Return on Equity

$$
\text { Merupakan rasio yang }
$$
menggambarkan kesuksesan manajemen dalam memaksimalkan tingkat pengembalian bagi pemegang saham. Return on Equity didapatkan dari laporan kevangan dalam annual report perusahaan selama periode 2009-2013 yang dipublikasikan di situs resmi BEl. Ukuran return on equity adalah rasio.

Rumus: Return on Equity $=\frac{\begin{array}{l}\text { Earning After } \\ \text { Taxes }\end{array}}{\text { Total Equity }}$

\section{Jenis dan Sumber Data}

Sumber data penelitian ini adalah data sekunder berupa laporan keuangan perusahaan yang dipublikasikan di situs resmi Bursa Efek Indonesia atau situs resmi perusahaan yang bersangkutan, serta data harga saham yang juga dipublikasikan.

\section{Prosedur Pengumpulan Data}

Data didapatkan dengan
mengunduh laporan keuangan
perusahaan tahunan yang dipublikasikan di situs resmi Bursa Efek Indonesia selama periode pengamatan. Data variabel dependen didapatkan dengan mengunduh histori harga saham yang dipublikasikan di situs resmi yahoo finance.

\section{Prosedur Penentuan Populasi}

Populasi dalam penelitian ini adalah seluruh perusahaan yang terdaftar pada Jakarta Islamic Index, dan mempublikasikan laporan keuangan yang lengkap. Untuk penggunaan subjek observasi pada penelitian ini digunakan perusahaan yang konsisten terdaftar di JII pada masa penelitian yaitu tahun 2009 sampai tahun 2013. Metode pemilihan subjek observasi menggunakan metode populasi yang dikriteriakan.

\section{Teknik Analisis}

Data yang digunakan dalam penelitian ini adalah data panel yang terdiri dari 13 perusahaan, yang diamati adalah cross section dan merupakan data keuangan selama lima tahun yang berarti time series. Sehingga persamaan yang ada dalam model analisis diubah menjadi:

$Y=\beta_{0}+\beta_{1} X_{1 i t}+\beta_{2} X_{2 i t}+\beta_{3} X_{3 i t}+\beta_{4} X_{4 i t}+e_{i t}$

$i$ (unit cross sectional) $=1,2,3,4, \ldots . .13$ 
$\dagger($ time identifier $)=1,2,3,4,5$

\section{Asumsi Klasik}

Pengujian jenis ini digunakan untuk menguji asumsi, apakah model regresi yang digunakan dalam penelitian ini layak atau tidak. Uji penyimpangan asumsi klasik mencakup:

1. Uji Normalitas

2. Uji Multikolonieritas

3. Uji Autokorelasi

4. Uji Heteroskedastisitas

\section{Uji Hipotesis}

\begin{tabular}{|l|l|r|r|}
\hline \multicolumn{2}{|l|}{ Model } & \multicolumn{2}{c|}{ Collinearity Statistics } \\
\cline { 3 - 4 } \multicolumn{2}{|c|}{} & Tolerance & VIF \\
\hline \multirow{4}{*}{1} & CR &, 854 & 1,171 \\
\cline { 2 - 4 } & TATO &, 806 & 1,240 \\
\cline { 2 - 4 } & DER &, 875 & 1,142 \\
\cline { 2 - 4 } & ROE &, 733 & 1,363 \\
\hline \multicolumn{2}{|l|}{ a. Dependent Variable: Harga Saham } \\
\hline
\end{tabular}

1. Pengujian secara parsial (Uji t)

2. Uji Simultan (Uji F)

3. Koefisien Determinasi $\left(R^{2}\right)$

\section{HASIL DAN PEMBAHASAN}

Uji Normalitas

Uji normalitas dilakukan untuk menghindari terjadinya bias pada model regresi. Metode untuk mengetahui normalitas data adalah dengan menggunakan analisis grafik yang melihat grafik Normal P-P Plot Of Regresion Standardized Residual. Uji normalitas dengan Normal Probability Plot dilihat pada gambar berikut:

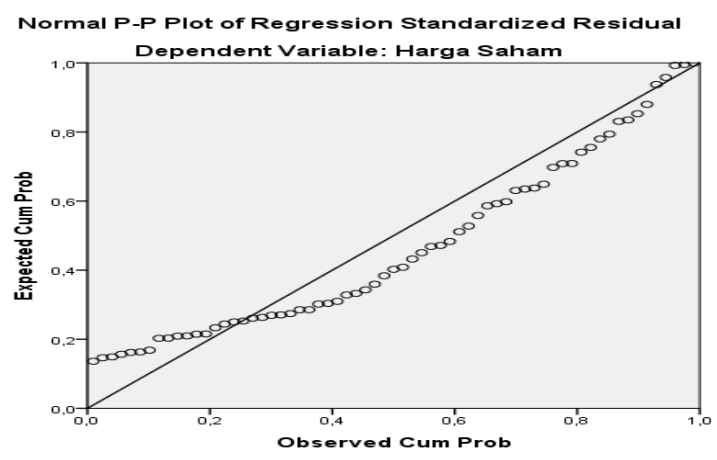

Sumber: data sekunder diolah.

Gambar 3

Normal Probability Plot

Dari gambar di atas, dapat dilihat bahwa data dalam model regresi dengan variabel dependen harga saham memenuhi asumsi normalitas data.

\section{Uji Multikolinearitas}

Suatu model persamaan regresi harus bebas dari gejala multikolinearitas yang berarti tidak terdapat korelasi yang kuat antar variabel independen, dengan syarat nilai variance inflation factor (VIF) $<10$ dan nilai tolerance value-nya $>0,10$.

Tabel 2

Coefficientsa

Sumber: data sekunder diolah

Hasil uji multikolinearitas pada Tabel menunjukkan bahwa:

a. Nilai VIF variabel Current Ratio 1,171 < 10, dan tolerance value $0,854>0,1$ maka variabel Current Ratio dinyataan bebas multikolinearitas.

b. Nilai VIF variabel Total Assets Turnover $1,240<10$, dan tolerance value 0,806 > 0,1, maka variabel Total Assets Turnover dinyataan bebas multikolinearitas.

c. Nilai VIF variabel Debt to Equity Ratio $1,142<10$, dan tolerance value 0,875 > 
0,1 maka variabel Debt to Equity Ratio dinyataan bebas multikolinearitas.

d. Nilai VIF variabel Return On Equity 1,363

$<10$, dan tolerance value $0,733>0,1$ maka variabel Return On Equity dinyataan bebas multikolinearitas.

\section{Uji Autokorelasi}

Uji autokorelasi digunakan untuk mengetahui ada atau tidaknya korelasi yang terjadi antara residual pada satu pengamatan dengan pengamatan lain pada model regresi. Prasyarat yang harus terpenuhi adalah tidak ada autokorelasi pada model regresi.

Tabel 3

Model Summaryb

\begin{tabular}{l|c|r|r|r|r|}
\hline $\begin{array}{l}\text { Mo } \\
\text { del }\end{array}$ & $R$ & $\begin{array}{r}R \\
\text { Squar } \\
\text { e }\end{array}$ & $\begin{array}{r}\text { Adjusted } \\
\text { R Square }\end{array}$ & $\begin{array}{r}\text { Std. Error } \\
\text { of the } \\
\text { Estimate }\end{array}$ & $\begin{array}{r}\text { Durbin- } \\
\text { Watson }\end{array}$ \\
\hline 1 &, $379 a$ &, 144 &, 086 & $\begin{array}{r}13568,10 \\
688\end{array}$ & 2,289 \\
\hline
\end{tabular}
a. Predictors: (Constant), ROE, DER, CR, TATO
b. Dependent Variable: Harga Saham
Sumber: data sekunder diolah

Nilai Durbin-Watson sebesar 2,289, jika bandingkan dengan nilai Tabel Durbin-Watson dengan $k=4$ dan $n=65$ didapat nilai $d=1,50349$ dan $d u=1,69602$. Nilai Durbin-Watson berada pada $d u<d w<4-d u$ yaitu 2,289, berarti tidak ada autokorelasi positif dan negatif.

\section{Uji Heteroskedastisitas}

Uji Heteroskedastisitas digunakan untuk mengetahui ada atau tidaknya ketidaksamaan varian dari residual pada model regresi. Prasyarat yang harus terpenuhi dalam model regresi adalah tidak ada masalah heteroskedastisitas. Untuk menentukan heteroskedastisitas dapat menggunkan grafik scatterplot, titik-titik harus menyebar secara acak, tersebar baik di atas maupun dibawah angka nol pada sumbu Y. Hasil uji heterokedastisitas dengan menggunakan grafik scatterplot di tunjukkan gambar berikut:

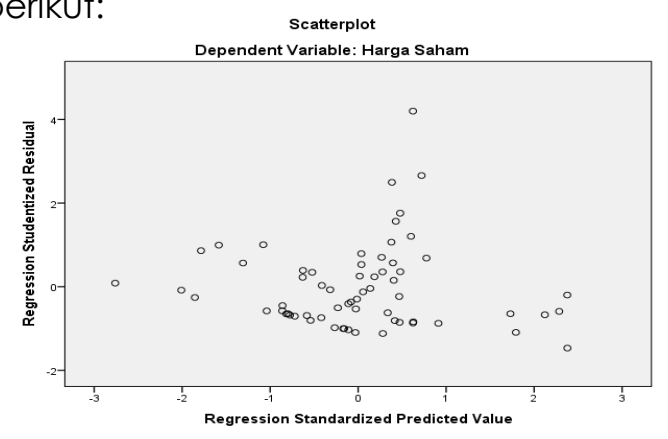

Sumber: data sekunder diolah

Gambar 4

Grafik Scatterplot

Dalam gambar grafik scatterplots terlihat bahwa titik-titik menyebar secara acak, di atas maupun di bawah angka nol pada sumbu Y. Dengan demikian dapat disimpulkan bahwa tidak terjadi masalah heterokedastisitas pada model regresi yang digunakan.

\section{Pengujian Analisis Model Regresi}

Analisis regresi linier berganda adalah hubungan secara linear antara dua atau lebih variabel independen dengan variabel dependen. Analisis ini memprediksi nilai dari variabel dependen apabila nilai variabel independen mengalami kenaikan atau penurunan dan untuk mengetahui arah hubungan antara variabel independen dengan variabel dependen, berhubungan positif atau negatif. Dalam penelitian ini yang menggunakan bantuan komputer program SPSS 20, hasilnya dapat dilihat pada Tabel berikut:

Tabel 4

Coefficientsa 


\begin{tabular}{|c|c|c|c|c|c|}
\hline \multirow[t]{2}{*}{ Model } & \multicolumn{2}{|c|}{$\begin{array}{l}\text { Unstandardized } \\
\text { Coefficients }\end{array}$} & \multirow{2}{*}{$\begin{array}{c}\begin{array}{c}\text { Standar } \\
\text { dized } \\
\text { Coeffici } \\
\text { ents }\end{array} \\
\text { Beta }\end{array}$} & \multirow[t]{2}{*}{$\mathrm{T}$} & \multirow[t]{2}{*}{ Sig. } \\
\hline & $B$ & $\begin{array}{l}\text { Std. } \\
\text { Error }\end{array}$ & & & \\
\hline $\begin{array}{l}\text { (Const } \\
\text { ant) }\end{array}$ & $\begin{array}{r}14216,9 \\
48\end{array}$ & $\begin{array}{r}5707,17 \\
2\end{array}$ & & 2,491 & ,016 \\
\hline CR & $\begin{array}{r}1765,02 \\
9\end{array}$ & 911,898 &,- 250 & 1,936 & ,058 \\
\hline${ }^{1}$ TATO & $\begin{array}{r}3028,20 \\
2\end{array}$ & $\begin{array}{r}1998,37 \\
7\end{array}$ & 202 & 1,515 & , 135 \\
\hline DER & $\begin{array}{r}6466,87 \\
5\end{array}$ & $\begin{array}{r}13901,6 \\
22\end{array}$ & ,059 & ,465 & ,643 \\
\hline $\mathrm{ROE}$ & $\begin{array}{r}5825,33 \\
9\end{array}$ & $\begin{array}{r}8186,78 \\
0\end{array}$ & .099 & 712 & 479 \\
\hline
\end{tabular}

a. Dependent Variable: Harga Saham

Sumber: data sekunder diolah

Berdasarkan model persamaan

yang telah dibahas pada bab sebelumnya, Tabel di atas menunjukkan hasil persamaan regresi. Tetapi hasil dari penelitian ini menunjukkan pengaruh variabel independen tidak signifikan, sehingga koefisien regresi ( $\beta$ ) dianggap bernilai nol, dan hasil persamaan regresi tidak perlu diinterpretasikan karena dianggap tidak bermakna.

\section{Pembuktian Hipotesis}

1. Pengujian secara parsial (Uji t)

Pengambilan keputusan dilakukan dengan membandingkan nilai † hitung dari masing-masing koefisien regresi dengan nilai † Tabel (nilai kritis) dan nilai signifikansi sesuai taraf signifikansi yang digunakan pada penelitian ini yaitu 0,05 . Variabel independen Current Ratio, Total Assets Turnover, Debt to Equity Ratio, dan Return On Equity dinyatakan berpengaruh signifikan terhadap harga saham apabila nilai signifikansi $\dagger$ hitung berada dibawah atau sama dengan 0,05, apabila nialinya berada di atas 0,05 maka dinyatakan berpengaruh tidak signifiakn terhadap harga saham.

Tabel 5.

Berdasarkan Tabel diperoleh nilai † hitung Current Ratio -1,936, † hitung untuk Total Assets Turnover 1,515, † hitung Debt to Equity Ratio 0,465, dan t hitung Return On Equity 0,712, sedangkan nilai † Tabel dengan taraf signifikan $5 \%$ sebesar 1.671 .

- Nilai t hitung Current Ratio -1,936, dan † Tabel 1,671, berarti († hitung < † Tabel) dan nilai signifikansi dari t hitung adalah 0,058 yaitu lebih besar dari 0,05. Berarti bahwa Current Ratio berpengaruh tidak signifikan terhadap harga saham perusahaan yang terdaftar di Jll pada periode 2009-2013.

- Nilai $\dagger$ hitung Total Assets Turnover 1,515, dan † Tabel 1,671, berarti († hitung $<\dagger$ Tabel) dan nilai signifikansi dari $\dagger$ hitung adalah 0,135 yaitu lebih besar dari 0,05. Berarti bahwa Total Assets Turnover berpengaruh tidak signifikan terhadap harga saham perusahaan

Coefficientsa (Hasil Uji †)

\begin{tabular}{|c|c|c|c|c|c|}
\hline \multirow[t]{2}{*}{ Model } & \multicolumn{2}{|c|}{$\begin{array}{l}\text { Unstandardized } \\
\text { Coefficients }\end{array}$} & \multirow{2}{*}{$\begin{array}{c}\begin{array}{c}\text { Standar } \\
\text { dized } \\
\text { Coeffici } \\
\text { ents }\end{array} \\
\text { Beta }\end{array}$} & \multirow[t]{2}{*}{$\mathrm{T}$} & \multirow[t]{2}{*}{ Sig. } \\
\hline & $B$ & $\begin{array}{l}\text { Std. } \\
\text { Error }\end{array}$ & & & \\
\hline $\begin{array}{l}\text { (Cons } \\
\text { tant) }\end{array}$ & $\begin{array}{r}14216 \\
948\end{array}$ & $\begin{array}{r}5707,17 \\
2\end{array}$ & & 2,491 &, 016 \\
\hline CR & $\begin{array}{r}1765,0 \\
29\end{array}$ & 911,898 &,- 250 & $1,936^{-}$ &, 058 \\
\hline${ }^{1}$ TATO & $\begin{array}{r}3028,2 \\
02\end{array}$ & $\begin{array}{r}1998,37 \\
7\end{array}$ & 202 & 1,515 & , 135 \\
\hline DER & $\begin{array}{r}6466,8 \\
75\end{array}$ & $\begin{array}{r}13901,6 \\
22\end{array}$ & ,059 & 465 & ,643 \\
\hline ROE & $\begin{array}{r}5825,3 \\
39\end{array}$ & $\begin{array}{r}8186,78 \\
0\end{array}$ & ,099 & ,712 & 479 \\
\hline
\end{tabular}

a. Dependent Variable: Harga Saham Sumber: Data Sekunder diolah 
yang terdaftar di Jll pada periode 2009-2013.

- Nilai t hitung Debt to Equity Ratio 0,465, dan $\dagger$ Tabel 1,671, berarti († hitung $<\dagger$ Tabel) dan nilai signifikansi dari t hitung adalah 0,643 yaitu lebih besar dari 0,05. Berarti bahwa Debt to Equity Ratio berpengaruh tidak signifikan terhadap harga saham perusahaan yang terdaftar di JII pada periode 2009-2013.

- Nilai † hitung Return On Equity 0,712, dan $\dagger$ Tabel 1,671, berarti († hitung $<\dagger$ Tabel) dan nilai signifikansi dari t hitung adalah 0,479 yaitu lebih besar dari 0,05. Berarti bahwa Return On Equity berpengaruh tidak signifikan terhadap harga saham perusahaan yang terdaftar di Jll pada periode 2009-2013.

2. Pengujian secara simultan (Uji F)

Uji F digunakan untuk mengetahui pengaruh variabel independen Current Ratio, Total Assets Turnover, Debt to Equity Ratio, dan Return On Equity secara simultan terhadap variabel dependen harga saham, dengan cara membandingkan $\mathrm{F}$ hitung dengan $\mathrm{F}$ Tabel, yang ditunjukkan dalam Tabel berikut:

Tabel 6.

ANOVAa (Hasil Uji F)

\begin{tabular}{|l|r|r|r|r|l|}
\hline Model & $\begin{array}{c}\text { Sum of } \\
\text { Squares }\end{array}$ & $\begin{array}{r}\text { D } \\
f\end{array}$ & $\begin{array}{c}\text { Mean } \\
\text { Square }\end{array}$ & F & Sig. \\
\hline Regres & 1851965 & 4 & 462991264,4 & 2,515 &, $051^{b}$ \\
sion & 057,675 & 19 & & \\
1 & & & & & \\
Residu & 1104561 & 6 & 184093524,2 & & \\
al & 1454,446 & 0 & 41 & & \\
Total & 1289757 & 6 & & & \\
\hline
\end{tabular}

a. Dependent Variable: Harga Saham a. Predictors: (Constant), ROE, DER, CR, TATO Sumber: Data sekunder diolah

Dari hasil analisis regresi dapat diketahui bahwa secara bersama-sama (simultan) variabel independen memiliki pengaruh yang tidak signifikan terhadap variabel dependen. Hal ini dapat dibuktikan dari nilai $F$ hitung sebesar 2,515 sedangkan nilai $F$ Tabel pada taraf signifikan $5 \%$ sebesar 2,76 sehingga dari hasil penghitungan tampak bahwa $F$ hitung lebih rendah dari F Tabel $(2,515<$ $2,76)$, dan nilai signifikansi adalah sebesar 0,051 atau dapat dikatakan lebih besar dari 0,05 sehingga menolak $\mathrm{Hl}$ dan menerima HO. Dengan demikian, maka model regresi tidak dapat digunakan untuk memprediksi harga saham atau dapat dikatakan bahwa Current Ratio, Total Assets Turnover, Debt to Equity Ratio, dan Return On Equity secara bersamasama berpengaruh tidak signifikan terhadap harga saham.

3. Koefisien Determinasi

Koefisien determinasi berfungsi untuk melihat sejauhmana keseluruhan variabel independen dapat menjelaskan variabel dependen. Apabila $R^{2}$ sama dengan nol, maka variasi variabel independen yang digunakan dalam model tidak menjelaskan sedikit pun variasi variabel dependen. Jika $R^{2}$ sama dengan satu, maka variasi variabel independen yang digunakan dalam model menjelaskan $100 \%$ variasi variabel dependen. Besarnya nilai koefisien determinasi dapat dijelaskan pada Tabel berikut: 
Tabel 7.

Model Summaryb (Hasil Uji Koefisien Determinasi)

\begin{tabular}{|l|r|r|r|r|}
\hline $\begin{array}{l}\text { Mod } \\
\text { el }\end{array}$ & \multicolumn{1}{|c|}{$\mathrm{R}$} & $\begin{array}{c}\mathrm{R} \\
\text { Square }\end{array}$ & $\begin{array}{c}\text { Adjusted R } \\
\text { Square }\end{array}$ & $\begin{array}{l}\text { Std. Error of } \\
\text { the Estimate }\end{array}$ \\
\hline 1 &, $379 a$ &, 144 &, 086 & 13568,10688 \\
\hline
\end{tabular}

a. Predictors: (Constant), ROE, DER, CR, TATO

b. Dependent Variable: Harga Saham Sumber: data sekunder diolah

Berdasarkan hasil penghitungan SPSS seperti pada Tabel di atas dapat diketahui bahwa pengaruh keempat variabel bebas (independen) terhadap variabel harga saham dinyatakan dengan nilai koefisien determinasi $\left(R^{2}\right)$ yaitu sebesar 0,144 atau $14,4 \%$. Hal ini berarti $14,4 \%$ variasi harga saham yang bisa dijelaskan oleh variasi dari keempat variabel indepenen yaitu Current Ratio, Total Assets Turnover, Debt to Equity Ratio, dan Return On Equity. Sedangkan sisanya sebesar $100 \%-14,4 \%=85,6 \%$ dijelaskan oleh sebab-sebab lain di luar model. Nilai $R^{2}$ yang hanya mencapai $14,4 \%$ dalam model ini, terbilang cukup rendah dan sangat jauh dari nilai $100 \%$. Karena dengan empat variabel yaitu Current Ratio, Total Assets Turnover, Debt to Equity Ratio, dan Return On Equity hanya dapat menjelaskan secara teoritik 14,4\% pergerakan perubahan harga saham.

\section{Pembahasan}

Menurut uji asumsi klasik yang dilakukan pada variabel-variabel penelitian ini, tidak ditemukan data yang bias. Uji normalitas menunjukkan variablevariabel dalam penelitian mempunyai distribusi normal. Uji multikolinearitas menunjukkan tidak ada hubungan antara masing-masing variabel, hal ini membuktikan bahwa bebas dari multikolinearitas. Pada Uji Autokorelasi, nilai durbin watson berada di atas nilai du sehingga menunjukkan antar variabel bebas dari autokorelasi positif maupun negatif. Pada uji heteroskedastisitas, tidak terdapat hubungan antara variabel dependen dengan variabel independen, sehingga bebas dari heteroskedastisitas.

1. Pengaruh Current Ratio Terhadap Harga Saham

Hasil penelitian menunjukkan Current Ratio berpengaruh tidak signifikan terhadap harga saham. Nilai signifikansi Current Ratio berada di atas level of significance $5 \%$ yaitu 0,58 . Hasil ini sesuai dengan penelitian yang dilakukan oleh Tarigan (2013) yang menyatakan pengaruh Current Ratio terhadap harga saham tidak signifikan. Menurut Weston dan Brigham (1993:295) rasio lancar merupakan satu-satunya indikator terbaik yang menunjukkan sejauh mana kewajiban lancar dipenuhi dengan aktiva lancar, dan disebutkan pula bahwa rasio ini paling lazim digunakan sebagai ukuran dari solvensi jangka pendek. Akan tetapi hasil dari penelitian ini menunjukkan bahwa pengaruh Current Ratio terhadap harga saham adalah tidak signifikan, hal ini berarti dalam realita pasar modal para investor tidak begitu memperhitungkan baik buruknya kemampuan likuiditas perusahaan dalam mengambil keputusan untuk menempatkan dana investasinya. Menurut Fraser dan Ormiston (2008:225) 
"sebagai suatu barometer likuiditas jangka pendek, rasio lancar dibatasi dengan sifat dari komponennya". Pengaruh Current Ratio terhadap harga saham tidak signifikan, kemungkinan dikarenakan investor menyadari keterbatasan rasio tersebut. Sebagaimana pendapat Fraser dan Ormiston (2008:225) bahwa piutang usaha dan persediaan tidak sepenuhnya likuid. Sedangkan kedua akun tersebut terlibat dalam penghitungan rasio lancar. Investor menyadari bahwa Current Ratio memiliki beberapa keterbatasan dan kelemahan sehingga investor berusaha mengimbangi dengan menggunakan informasi yang lain sebagai bahan untuk mendukung keputusannya (Tarigan, 2013:102).

2. Pengaruh Total Assets Turnover Terhadap Harga Saham

Hasil penelitian menunjukkan Total Assets Turnover berpengaruh tidak signifikan terhadap harga saham. Nilai signifikansi Total Assets Turnover berada di atas level of significance $5 \%$ yaitu 0,135. Hasil ini menolak penelitian yang dilakukan oleh RM Kusumo (2011) yang hasilnya menunjukkan pengaruh signifikan Total Assets Turnover terhadap return saham, sedangkan return saham dihitung dari terjadinya tingkat keuntungan dari selisih atau perubahan harga saham. Dalam kinerja keuangan perusahaan Total Assets Turnover dihitung dengan membagi penjualan dengan total aktiva (Weston dan Brigham, 1993:299). Sehingga Total Assets Turnover menunjukkan kemampuan perusahaan dalam memafaatkan aset-aset yang dimiliki untuk menghasilkan penjualan ataupun pendapatan. Akan tetapi hasil dari penelitian ini menunjukkan bahwa pengaruh Total Assets Turnover terhadap harga saham tidak signifikan, hal ini berarti dalam realita pasar modal para investor dalam mengambil keputusan untuk menempatkan dana investasinya tidak begitu memperhitungkan baik buruknya kemampuan operasional perusahaan dalam menghasilkan pendapatan. Menurut Weston dan Brigham (1993:288) "inflasi menyebabkan nilai sejumlah besar aktiva yang dibeli pada waktu yang lalu menjadi sangat kecil". Oleh sebab itu pada beberapa perusahaan yang sudah berdiri sejak lama akan memiliki nilai perputaran aktiva yang lebih tinggi jika dibanding perusahaan yang memperoleh aktiva pada saat sudah terjadi inflasi. Kemungkinan investor menyadari hal tersebut sehingga tidak menggunakan Total Assets Turnover sebagai dasar utama pengambilan keputan, jadi pengaruh Total Assets Turnover terhadap harga saham menjadi tidak signifikan.

3. Pengaruh Debt to Equity Ratio Terhadap Harga Saham

Hasil penelitian menunjukkan Debt to Equity Ratio berpengaruh tidak signifikan terhadap harga saham. Nilai signifikansi Debt to Equity Ratio berada di atas level of significance $5 \%$ yaitu 0,643 . Hasil ini sesuai dengan penelitian yang dilakukan oleh RM Kusumo (2011) dan menolak hasil penelitian Thamrin (2012), karena hasilnya menunjukkan Debt to Equity Ratio 
memiliki pengaruh signifikan terhadap return saham sementara return saham didapatkan dan dihitung dengan harga saham. Dalam kinerja keuangan perusahaan Debt to Equity Ratio melibatkan akun-akun yang menunjukkan kemampuan ekuitas perusahaan dalam mengcover hutangnya yaitu hutang jangka panjang, sehingga Debt to Equity Ratio menunjukkan besarnya perbandingan antara hutang jangka panjang terhadap ekuitas pemegang saham perusahaan (Sundjaja dan Barlian, 2003:141), atau menunjukkan kemampuan perusahaan dalam memenuhi kewajiban jangka panjangnya. Akan tetapi hasil dari penelitian ini menunjukkan bahwa ternyata pengaruh Debt to Equity Ratio terhadap harga saham tidak signifikan, hal ini berarti dalam realita pasar modal para investor dalam mengambil keputusan untuk menempatkan dana investasinya tidak begitu memperhitungkan baik buruknya kemampuan perusahaan dalam memenuhi kewajiban hutang jangka panjang atau tidak memperhitungkan risiko kerugian apabila terjadi kebangkrutan pada perusahaan tersebut karena apabila perusahaan mengalami kebangkrutan yang mendapat jaminan pengembalian dana adalah pihak kreditur bukan investor. Menurut Sundjaja dan Barlian (2003:139) kewajiban atau tuntutan terhadap kreditur harus lebih didahulukan daripada pembagian hasil kepada pemegang saham. Menurut Fraser dan Ormiston (2008:233) seorang analis harus hati-hati bahwa rasio hutang tidak menyajikan gambaran yang menyeluruh tentang risiko. Kemungkinan banyak investor yang memahami bahwa rasio hutang bukan gambaran risiko yang tepat bagi perusahaan, sehingga para investor mengabaikan nilai Debt to Equity Ratio perusahaan dalam pengambilan keputusannya. Oleh karena itu pengaruh Debt to Equity Ratio terhadap harga saham tidak signifikan.

\section{Pengaruh Return On Equity Terhadap Harga Saham \\ Hasil penelitian menunjukkan Return} On Equity berpengaruh tidak signifikan terhadap harga saham. Nilai signifikansi Return On Equity berada di atas level of significance $5 \%$ yaitu 0,479 . Hasil ini menolak hasil penelitian yang dilakukan Deitiana (2011) yang hasilnya menunjukkan pengaruh signifikan antara Return On Equity terhadap harga saham. Dalam kinerja keuangan perusahaan Return On Equity melibatkan akun-akun yang menunjukkan kemampuan perusahaan menghasilkan laba yaitu laba bersih, sehingga Return On Equity menunjukkan kemampuan perusahaan dalam memafaatkan ekuitas yang dimiliki untuk menghasilkan laba bersih. Return On Equity dikalkulasi sebagai pengembalian atas ekuitas saham biasa jika perusahaan memiliki saham preferen yang beredar (Fraser dan Ormiston, 2008:238). Akan tetapi hasil dari penelitian ini menunjukkan bahwa pengaruh Return On Equity terhadap harga saham tidak signifikan, hal ini berarti dalam realita pasar modal 
para investor dalam mengambil keputusan untuk menempatkan dana investasinya tidak begitu memperhitungkan baik buruknya kemampuan operasional perusahaan dalam menghasilkan laba bersih, yang pada dasarnya laba bersih nantinya akan dibagikan kepada para investor berupa dividen. Kemungkinan investor lebih mengharapkan keuntungan dari selisih harga jual dan beli daripada keuntungan berupa dividen mengingat dividen dibagikan dalam jangka waktu yang lama. Selain itu faktor corporate action (stock split) yang dilakukan oleh salah satu subjek penelitian pada tahun 2012 dimungkinan lebih mempengaruhi keputusan investor sehingga pengaruh rasio keuangan sebagai ukuran kinerja kinerja keuangan hasilnya tidak signifikan.

5. Pengaruh Current Ratio, Total Asset Turnover, Debt to Equity Ratio, dan Return on Equity Secara Simultan Terhadap Harga Saham

Hasil penelitian menunjukkan bahwa Current Ratio, Total Asset Turnover, Debt to Equity Ratio, dan Return on Equity secara bersama-sama berpengaruh tidak signifikan terhadap harga saham. Nilai signifikansi pada hasil uji $\mathrm{F}$ berada di atas level of significance $5 \%$ yaitu 0,051 . Hasil ini tidak sesuai dengan penelitian yang dilakukan oleh Vice dan Lauw (2011) yang menunjukkan pengaruh signifikan secara simultan variabel Current Ratio bersama dengan variabel independen yang lain terhadap harga saham, dan juga tidak sesuai dengan penelitian Tarigan (2013) yang menunjukkan secara simultan Current Ratio dan Erning Per Share (EPS) berpengaruh signifikan terhadap harga saham. Hal ini berarti dalam realita pasar modal para investor dalam mengambil keputusan untuk menempatkan dana investasinya tidak begitu memperhitungkan nilai dari keempat variabel independen tersebut. Kemungkinan ada faktor lain yang lebih mempengaruhi pergerakan harga saham, salah satunya dikarenakan adanya corporate action yang dilakukan oleh salah satu subjek penelitian pada masa penelitian yaitu tahun 2012. PT Astra Internasional Indonesia Tbk. (ASII) melakukan stock split sebesar 10:1, sehingga menunjukkan data harga saham yang seakan-akan mengalami penurunan yang drastis. Menurut Fahmi (2013:30) walaupun investor mempunyai informasi yang cukup mengenai perusahaan tetapi asimetri informasi tetap terjadi dalam penawaran. Sehingga walaupun informasi berhasil sampai kepada investor akan tetapi yang ditangkap investor dimungkinkan ada gap informasi dengan manajemen perusahaan. Kemungkinan karena terjadi hal-hal tersebut maka pengaruh keempat variabel Current Ratio, Total Asset Turnover, Debt to Equity Ratio, dan Return on Equity terhadap harga saham tidak signifikan.

\section{Simpulan}

Berdasarkan hasil analisis data yang mengacu pada tujuan penelitian, hipotesis, dan model analisis, maka dapat ditarik kesimpulan sebagai berikut: 
1. Berdasarkan hasil penghitungan uji $\dagger$ menunjukkan bahwa variabel Current Ratio, Total Assets Turnover, Debt to Equity Ratio, dan Return On Equity secara parsial masing-masing berpengaruh tidak signifikan terhadap harga saham.

2. Berdasarkan hasil penghitungan uji $F$ menunjukkan bahwa variabel Current Ratio, Total Assets Turnover, Debt to Equity Ratio, dan Return On Equity secara simultan berpengaruh tidak signifikan terhadap harga saham.

\section{Saran}

Berdasarkan hasil penelitian terdapat beberapa saran untuk pihakpihak yang yang terkait, yaitu perusahaan, investor, dan peneliti yang akan meneliti hal serupa di masa yang akan datang, yaitu :

1. Perusahaan-perusahaan di Indonesia sebaiknya mulai memperhatikan pengelolaan dan pemanfaatan asetaset yang dimiliki, serta memaksimalkan kinerjanya dengan efektif dan efisien. Dari hasil penelitian yang menunjukkan tidak adanya pengaruh signifikan antara variabel independen dengan variabel dependen menunjukkan bahwa harga saham benar-benar ditentukan oleh pasar yang dikendalikan oleh penawaran dan permintaan berdasarkan keputusan investor dalam memperkirakan penempatan dananya.

2. Bagi investor sebaiknya benar-benar memperhatikan faktor-faktor lain yang mempengaruhi harga saham, selain variabel independen pada penelitian ini. Terutama kondisi realita perusahaan dengan corporate action yang dilakukan perusahaan, serta isu-isu yang terjadi di pasar modal.

3. Bagi penelitian selanjutnya, mungkin dapat menambah atau memperpanjang periode penelitian dan jumlah data pada penelitian. Dan mungkin juga variabel-variabel bebas lainnya yang berhubungan dengan harga saham.

\section{DAFTAR PUSTAKA}

Adlany, Nazri., dkk. 2005. Al Quran Terjemah Indonesia. Jakarta: Sari Agung.

Darsono, dan Ashari. 2005. Pedoman Praktis Memahami Laporan Kevangan. Yogyakarta: Andi.

Deitiana, Tita. 2011. Pengaruh Rasio Keuangan, Pertumbuhan Penjualan, dan Dividen Terhadap Harga Saham. Jurnal Bisnis dan Akuntansi. 13 (1): 57-66. Fahmi, Irham. 2013. Pengantar Pasar Modal. Bandung: Alfabeta.

Fraser, L. M., dan Ormiston, Aileen. 2004. Memahami Laporan Keuangan. Edisi ketujuh. Terjemahan oleh Priyo Darmawan. 2008. Jakarta: Indeks.

Husnan, Suad. 2009. Dasar-Dasar Teori Portofolio dan Analisis Sekuritas. Yogyakarta: YKPN.

Ikatan Akuntan Indonesia. 2009. Pernyataan Standar Akuntansi Kevangan (Kerangka Dasar Penyusunan dan Penyajian Laporan Kevangan Syariah). Jakarta: Dewan Standar Akuntansi Keuangan IAI. 
Jogiyanto, H.M. 2013. Teori Portfolio dan Analisis Investasi. Yogyakarta: BPFE.

Noor, Henry Faizal. 2009. Investasi, Pengelolaan Keuangan Bisnis dan Pengembangan Ekonomi Masyarakat. Jakarta: Indeks.

Republik Indonesia. Undang-undang Pasar Modal No. 8 tahun 1995 tentang Pasar Modal.

RM Kusumo, Gian I. 2011. Analisis Pengaruh Rasio Keuangan terhadap Return Saham pada Perusahaan Non Bank LQ45. Skripsi Fakultas Ekonomika dan Bisnis Universitas Diponegoro Semarang.

Sudana, I Made. 2009. Manajemen Keuangan Teori dan Praktik. Surabaya: Airlangga University Press.

Sundjaja, Ridwan S., dan Barlian, Inge. 2003. Manajemen Keuangan Satu. Jakarta: Literata Lintas Media.

Syamsuddin, Lukman. 2009. Manajemen Kevangan Perusahaan Konsep Aplikasi dalam Perencanaan, Pengawasan, dan Pengambilan Keputusan. Jakarta: Raja Grafindo Persada.

Tampubolon, Manahan P. 2005. Manajemen Keuangan. Bogor: Ghalia Indonesia.

Tarigan, Nur Muhammad R. 2013. Pengaruh Likuiditas dan Profitabilitas terhadap Harga Saham Perusahaan Manufaktur yang Terdaftar di BEl. Jurnal Manajemen Bisnis. 1 (13): 80-104.

Thamrin, Yurlis. 2012. Analisis Current Ratio (CR) dan Debt Equity Ratio (DER) terhadap Return Saham Perusahaan Manufaktur yang Terdaftar di Bursa Efek
Indonesia. Skripsi Fakultas Ekonomi dan Bisnis Universitas Hasanuddin Makasar. Vice, Law Rien Sia, dan Lauw, Tjun Tjun. 2011. Pengaruh Current Ratio, Earnings per Share, dan Price Earnings Ratio Terhadap Harga Saham. Jurnal Akuntansi. 3 (2): 136-158.

Weston, J. F., dan Brigham, E. F. 1990. Dasar-dasar Manajemen Kevangan. Jilid 1. Edisi Kesembilan. Terjemahan oleh Alfonsus Sirait. 1993. Jakarta: Erlangga.

,-_dkk. - 1996. Essentials of Managerial Finance. Fort Worth: Driden Press.

www.dsnmui.or.id diakses pada Rabu 8 Oktober 2014. Pukul 15.15 WIB. www.finance.yahoo.com diakses pada Selasa 7 Oktober 2014. Pukul 5.35 WIB. www.idx.co.id diakses pada Selasa 7 Oktober 2014. Pukul 5.32 WIB. 